\title{
BERPIKIR PROFETIK \\ DALAM PEMBELAJARAN MATEMATIKA SD/MI
}

\author{
Azamul Fadhly Noor Muhammad
}

Program Studi PGSD STKIP Majenang

Email: fadhlee46@gmail.com

\begin{abstract}
ABSTRAK
Dalam dunia pendidikan para siswa yang memiliki minat belajar yang tinggi dapat mengalami penurunan minat belajarnya. Salah satu contoh dalam pembelajaran matematika. Jika mereka diajarkan oleh guru dengan cara yang membosankan dan monoton, maka siswa akan cepat bosan dalam menerima pembelajaran tersebut di kelas. Sebaiknya, siswa yang mempunyai motivasi rendah, dapat mengalami peningkatan minat belajar jika dibimbing oleh seorang guru yang mengetahui bagaimana cara berkomunikasi dan berpikir secara baik kepada siswanya. Berpikir profetik adalah berpikir sesuai dengan yang Nabi ajarkan atau lakukan. Pendidikan dengan perspektif profetik berarti mengkaji pendidikan sebagai program besar bangsa yang memiliki kekuatan prediktif ke masa depan yang lebih gemilang yang dilakukan oleh seseorang yang disebut nabi, yaitu orang yang berbicara awal atau pioner yang memproklamasikan diri dan berbicara masa depan. Dalam mengajarkan pelajaran matematika yang merupakan pelajaran yang sangat dibutuhkan oleh siswa sebagai bekal dia menjalani kehidupan di masyarakat kelak. Belum lagi paradaban bangsa kita saat ini yang sangat terpuruk, sehingga kita seolah-olah telah hilang jati diri sebagai bangsa yang bermartabat, sehingga dibutuhkan kembali tingkat berpikir sesuai yang diajarkan oleh Nabi Muhammad SAW yang sering kita sebut berpikir Profetik, yang sesungguhnya itu sudah diajarkan oleh orang tua masing-masing sebelum masuk SD.
\end{abstract}

\section{Kata Kunci: Berpikir Profetik, Pembelajaran, Matematika SD}

\begin{abstract}
In the world of education, students who have a high learning interest can experience a decrease in interest in learning. One example in mathematics learning. If they are taught by the teacher in a tedious and cheery way, then the students will get bored quickly in accepting the learning in class. Preferably, students who have low motivation, can experience increased interest in learning if guided by a teacher who knows how to communicate and think well to the students. Prophetic thinking is thinking according to what the prophet teaches or does. Education with prophetic perspective means studying education as a great nation program that has a predictive power to a more brilliant future conducted by someone called a prophet who is an early speech or pioneer who proclaims himself and speaks the future. In teaching Mathematics lesson which is a lesson that is needed by the students as their provision to live life in society later. Not to mention the paradaban of our nation at this time so badly, so we seem to have lost identity as a dignified nation, so it is necessary to return the level of thinking as taught by the Nabi Muhammad SAW that we often call Profetic thinking, which actually was already taught by parents each before entering elementary school.
\end{abstract}

Keywords: Profetical Thinking, Learning, Elementary Mathematics

AL-BIDAYAH: Jurnal Pendidikan Dasar Islam

Volume 9, Nomor 02, Desember 2017; ISSN: 2085-0034 


\section{PENDAHULUAN}

Guru adalah orang yang berperan penting dalam kegiatan pembelajaran, karena guru memegang tugas mengatur dan mengelola kehidupan kelas. Dalam melaksanakan tugas tersebut guru harus berupaya sekuat tenaga agar kehidupan kelasnya berjalan dengan baik, siswa dapat belajar tanpa hambatan, dan dapat menguasai apa yang diajarkan oleh guru secara maksimal. Dalam mengajar guru menggunakan strategi mengajar dan metode-metode yang paling baik dan sesuai, sehingga upaya guru ini dapat meningkatkan prestasi siswa.

Cara berpikir guru yang diterapkan di kelas dapat dikatakan baik bila menghasilkan sesuatu sesuai dengan yang direncanakan. Guru diharuskan mempunyai pandangan tentang pembelajaran yang luas, dimana pada saat pembelajaran dapat digunakan dalam mengajar agar siswa dapat dengan cepat memahami materi yang disampaikan olehnya. Siswa yang berada di dalam kelas berpengaruh terhadap keefektifan pembelajaran, yang mana guru harus menyampaikan pelajaran dengan merata. Kenyataannya sering kita melihat kelas yang hanya diajarkan oleh seorang guru dengan cara ceramah tanpa melibatkan siswa di dalamnya.

Dalam dunia pendidikan para siswa yang memiliki minat belajar yang tinggi dapat mengalami penurunan minat belajarnya. Salah satu contoh dalam pembelajaran matematika. Jika mereka diajarkan oleh guru dengan cara yang membosankan dan monoton, maka siswa akan cepat bosan dalam menerima pembelajaran tersebut di kelas. Sebaliknya, siswa yang mempunyai motivasi rendah, dapat mengalami peningkatan minat belajar jika dibimbing oleh seorang guru yang mengetahui bagaimana cara berkomunikasi dan berpikir secara baik kepada siswanya.

Seperti dicontohkan oleh Nabi Muhammad SAW, bahwa untuk masuk agama Islam tidak ada unsur paksaan bagi siapa saja yang ingin masuk $^{1}$. Hal ini menandakan bahwa Nabi Muhammad SAW dalam mengajak umatnya dalam memeluk dan mengajarkan agama Islam tidak ada unsur paksaan sama sekali. Tetapi lebih kepada unsur perilaku dan tindakan yang halus dan tidak keluar dari kebiasaan yang dianggap negatif dalam pandangan Islam. Nabi Muhammad SAW juga mengajarkan kepada kita agar selalu menyayangi dan mencintai sesama makhluk ciptaan Allah SWT. Tingkat berpikir seperti inilah yang kita sebut berpikir Profetik. Berpikir profetik adalah berpikir sesuai dengan yang Nabi ajarkan atau lakukan. Pendidikan dengan perspektif profetik atau kenabian berarti mengkaji pendidikan sebagai program besar bangsa yang memiliki kekuatan prediktif ke masa depan yang lebih gemilang yang dilakukan oleh seseorang yang disebut nabi, yaitu orang yang berbicara awal atau pioner yang memproklamasikan diri dan berbicara masa depan ${ }^{2}$.

Pemikiran guru yang beragama Islam hendaknya tidak jauh berbeda dengan yang Nabi Muhammad SAW ajarkan. Bilamana pembelajaran di kelas, guru diharapkan tidak memaksakan siswa untuk mendengarkan guru dalam menyampaikan materi, tetapi siswa diajak untuk dapat berpikir kritis tentang pembelajaran matematika. Karena banyak siswa yang gagal dalam belajarnya karena guru yang mengajarnya tidak memiliki basis keilmuan yang tinggi, ataupun metode yang digunakan oleh guru dalam pembelajaran matematika tidak sesuai dengan materi yang diajarkan.

Seiring dengan perkembangan teknologi,

1 Marti Lings, terjemahan, Muhammad: Kisah Hidup Nabi Berdasarkan Sumber Klasik (Jakarta: Serambi, 2007), hlm. 489-491

2 Mircea Eliade (ed.), The Encyclopedia of Religion, Vol. 12. (New York: Macmilan Publishing Company, 1987), hlm. 16 
kini dibutuhkan para guru yang mempunyai pemikiran yang maju dan kekinian agar dapat meningkatkan kemampuan belajar siswa dalam beberapa mata pelajaran dan berkemampuan dalam memilih metode pembelajaran yang tepat. Sehingga akan dapat memotivasi siswa untuk belajar lebih menyenangkan dan lebih mendalam.

Apalagi dalam mengajarkan pelajaran matematika yang merupakan pelajaran yang sangat dibutuhkan oleh siswa sebagai bekal dia menjalani kehidupan di masyarakat kelak. Belum lagi paradaban bangsa kita saat ini yang sangat terpuruk, sehingga kita seolah-olah telah kehilangan jati diri sebagai bangsa yang bermartabat, sehingga dibutuhkan kembali tingkat berpikir sesuai yang diajarkan oleh Nabi Muhammad SAW yang sering kita sebut berpikir Profetik, yang sesungguhnya itu sudah diajarkan oleh orang tua masing-masing sebelum masuk SD.

\section{PEMBAHASAN}

\section{Berpikir Profetik}

Hakikatnya manusia berpikir karena berpikir adalah keunggulan manusia, dan kemampuan berpikir hanya dimiliki manusia itu sendiri, dan tidak dimiliki oleh makhluk lainnya. Dengan berpikir, manusia dapat merumuskan konsep keilmuan dan dengan konsep keilmuannya, manusia dapat membentuk kebudayaan dan peradaban ${ }^{3}$. Secara etimologis, kata profetik berarti kenabian dan juga "nujum". Nabi mampu memberikan prediksi masa depan di dunia juga di akhirat ${ }^{4}$. Berpikir

$3 \quad$ Al-Zain. 'Ilmu an-Nafsi: Ma'rifah an-Nafsi alinsaniyah fi al-Kitab wa As-Sunnah. (Beirut: Dar Al-Kitab, 1991), hlm. 253

4 Save M Dagum. Kamus Besar Ilmu Pengetahuan, Edisi II, Cet. V. (Jakarta: Lembaga Pengkajian Kebudayaan Nusantara. 2006), hlm. 897 profetik lebih menekankan berpikir yang sesuai dengan pemikiran nabi, dalam Islam yang wajib kita anut adalah pemikiran Nabi Muhammad SAW. Metode berpikir profetik adalah metode berpikir hikmah untuk menemukan kebaikan yang terkandung dalam ayat Allah SAW, baik ayat-ayat yang terkandung di kehidupan alam semesta maupun seisinya. Kecerdasan dari akal sucinya menemukan hakikat makna di balik realitas yang ada dalam semua kehidupan ini.

Proses berpikir profetik dalam agama Islam yang berpatokan pada Al-Qur'an (3: 191), terdapat beberapa tahapan dalam proses berpikir. Pertama, mengingat kekuasaan Allah SWT dalam keadaan apapun sebagai titik tolak dalam berpikir. Dengan selalu mengingat kekuasaan Allah SWT dalam berpikir, hawa nafsu dan kepentingan kekuasaan pragmatis dapat disingkirkan. Manusia dapat berpikir bebas dan otentik untuk menemukan kebenaran itu sendiri, bukan untuk melegitimasi kepentingannya, baik kepentingan ideologi maupun kekuasaan.

Kedua, memikirkan tentang penciptaan langit dan bumi seisinya. Berpikir tentang penciptaan langit dan seisinya adalah berpikir pada proses penciptaanya, yaitu untuk menemukan mekanisme yang ada di dalamnya. Berpikir untuk menemukan bagaimana proses itu bekerja dalam mekanisme yang sistematik. Berpikir tentang proses ini akan dilahirkan konsep sains dan teknologi yang dalam perkembangannya sangat menentukan bagi kemajuan peradaban manusia.

Ketiga, berpikir yang didasarkan pada kesadaran atas kekuasaan Allah SWT yang akan melahirkan kesadaran transendental, yang memberi arah untuk apa semua proses pemikiran manusia dengan kemajuan konsep sains, matematika dan teknologi itu dilakukan. Dengan demikian, diharapkan agar dampak 
pemikiran manusia tidak mengakibatkan terjadinya keburukan dan kerusakan bagi kehidupan manusia sendiri. Sebaliknya sains, matematika, dan teknologi menjadi pengabdian kemanusiaan untuk menjauhkan diri manusia dari siksaan neraka ataupun dari kehancuran dan penderitaan manusia yang berada di dunia.

Karena itu berpikiran profetik atau kenabian harus selalu didasarkan pada kesadaran iman dan Islam kepada Allah SWT yang mutlak, dan secara bersamaan menisbikan kekuasaan manusia terbatas. Dengan demikian, kita akan memasuki tahap keempat dalam beribadah, mulai dari puncak pemikiran manusia di dunia sains, matematika, dan teknologi tidak digunakan untuk merusak dan membuat manusia menderita, tetapi kebalikannya, agar dapat bermanfaat bagi kehidupan manusia secara bersama-sama. Sains, matematika, dan teknologi menjadi perpanjangan dari ayat-ayat Allah SWT sendiri, dan menjadi cara manusia mengabdikan dirinya kepada Allah SWT dan manusia ${ }^{5}$.

Sumber otoritas yang paling penting bagi umat Islam setelah Al-Qur'an, adalah perilaku dan pemikiran normatif Nabi Muhammad (dikenal dengan nama sunnah). Sunnah secara harfiah berarti hukum adat dan praktik perilaku dan pemikiran yang lazim di Arab selama era pra-Islam. Bagi umat Islam, perilaku tersebut itu datang untuk mewakili perilaku normatif Nabi SAW.

Sunnah ini didokumentasikan dalam hadits. Awalnya, istilah hadits itu sederhana 'Baru' dan digunakan mengacu pada cerita

5 Harun Yahya, The Qur'an Leads the Way to Science, (Istanbul: Global Publishig, 2004), 8-18. atau laporan ${ }^{6}$. Kemudian, merujuk untuk informasi tentang Nabi Muhammad SAW, seperti ucapan dan perbuatannya dan uraian tentang orangnya, seperti dilansir oleh para sahabat. Sebelum Muhammad bin Idris alSyafi'i (wafat 204/819), setelah itu sekolah hukum Syafi'i yang berpengaruh diberi nama, perbedaan sering dibuat antara Sunnah dan hadits. Sunnah dipandang sebagai perilaku normatif Nabi didukung oleh praktik Muslim yang disepakati secara umum komunitas yang pada gilirannya didasarkan pada praktik Nabi dan Muslim paling awal. Fokusnya adalah pada 'praktik normatif'. Praktik ini mungkin atau mungkin tidak didukung oleh hadits tertentu. Yang mana ada praktik khusus yang diikuti oleh masyarakat dan ada juga hadits yang mendukung praktik itu, reliabilitas hadits tersebut diperkuat. Demikian pula ada hadits tapi tidak ada praktik pendukungnya, pertanyaan bisa diajukan tentang kebenaran hadits. Dari beberapa perbedaan yang jelas itu, maka perlu dibuat antara 'Sunnah' dan 'hadits' di sebuah situasi. Namun, dalam periode pascaSyafi'i, Sunnah disamakan dengan hadits. Bagi Syafi'i, hadits yang otentik adalah Sunnah dan ada praktik umum di masyarakat atau tidak untuk mendukung hadits tersebut.

Salah satu istilah yang paling sering digunakanuntukpemikiran profetik Islamadalah kalam. Di Bahasa Arab, kata kalam bisa berarti beberapa hal. Secara umum diterjemahkan itu mengacu pidato, debat, dan diskusi. Kalam adalah area pengetahuan yang berhubungan dengan keyakinan, bukti, dan keyakinan dasar agama, pertahanan melawan serangan terhadap fondasi iman dan Islam. Dalam hal ini tidak berurusan dengan bidang hukum. Sebaliknya,

$6 \quad$ Muhammad Mustafa Azami, Studies in Hadith Methodology and Literature, (American Trust, 1977, Kuala Lumpur: Islamic Book Trust), hlm. 32 
ini berpusat pada sistem kepercayaan yang mendasari Islam. Kalam justru menyimpang dari fiqih (yurisprudensi Islam) yang berfokus pada perbuatan, pemikiran, dan tindakan.

Awal dari bidang pengetahuan ini kembali ke periode paling awal sejarah Islam, ketika umat Islam mulai memperdebatkan kepercayaan agama. Masalahnya termasuk hal-hal seperti kesatuan Tuhan dan eksistensi dan atributatributnya, pemikiran kenabian, kitab suci dan wahyu, kebangkitan dan akhirat. Sementara banyak pemikiran yang berkembang melalui argumen untuk berbagai hal posisi teologis dan terlibat dalam perdebatan teologis. Beberapa muslim menentang argumen dan perdebatan itu. Mereka tidak percaya ada kebutuhan untuk disiplin pemikiran atau bagi umat Islam untuk terlibat dalam debat semacam itu sama sekali. Bagi mereka, kredo Islam secara nyata ditetapkan oleh Al-Qur'an dan dijelaskan oleh Nabi Muhammad SAW. Jadi tidak perlu membuktikan kepercayaan antara pemikiran muslim rasional dan tidak rasional. Prosedur seperti itu adalah sebuah inovasi dalam Islam, yang terkenal pernyataan 'Dia yang terlibat dalam kalam tidak akan pernah menerima keselamatan, karena tidak pernah seorang pria mengambil untuk kalam kecuali hatinya kurang dalam iman'?.

Setelah semuanya siap, potensi yang serba utama yang dimiliki oleh Nabi Muhammad SAW itu semakin melekat kuat pada dirinya sehingga ia dikenal memiliki sifat yang niscaya (wajib), yaitu jujur, amanah, komunikatif, dan cerdas. Dengan empat sifat kenabian itu ia menjadi figur yang selalu berpedoman pada nurani dan kebenaran (conscience center), menjaga profesionalisme dan komitmen

$\overline{7}$ Brill Leiden, "A. Rippin, Muslims: Their Religious Beliefs and Practices", Library of Religious Beliefs and Practices, London: Routledge, no.12 (1990), vol. 1, 63 (highly commited), mengusai keterampilan berkomunikasi (communication skill), sekaligus mampu menyelesaikan masalah (problem solver). Dalam konteks Islam praktik edukasi yang dilakukan dan diajarkan oleh Nabi Muhammad SAW, yaitu pertama nabi harus menguasai materi yang terkumpul dalam Al-Qur'an dan hadits yang sesuai dengan kebutuhan siswa atau umat sepanjang masa. Kedua, nabi juga menguasai metodologis yang efektif dan efesien sehingga pesan yang disampaikan menyentuh jiwa umat sebagai subjek didik. Ketiga, ia terus melakukan kontrol dan evaluasi mutu dengan amar ma'ruf (perintah melakukan hal positif), nahi munkar (larangan berbuat negatif), dan rekomendasi terkait dengan kebenaran (haq) dan kesabaran. Keempat, nabi memosisikan diri sebagai model ideal bagi umat (subjek didiknya) dalam berpikir, bersikap, berperilaku, dan menata masa depan di dunia dan akhirat. Secara personal dan sosial pribadi Nabi dapat menjadi delegasi (rasul) untuk menata moralitas dan spiritualitas semua manusia ${ }^{8}$.

Dalam usaha memperbaiki pembelajaran yang baik dan sesuai yang diharapkan, maka sifat-sifat Nabi Muhammad SAW tersebut dapat diterapkan pada proses pembelajaran di kelas. Keempat sifat Nabi tersebut bila diterapkan dalam pembelajaran adalah sebagai berikut.

1. Sifat jujur yang berpedoman pada nurani dan kebenaran (conscience center).

Guru mampu menyampaikan materi sesuai dengan buku sumber yang menjadi patokan dalam pembelajaran dan tidak boleh menambahnambahkan atau bahkan mengurangi materi

8 Moh Roqib, "Pendidikan Karakter Dalam Perspektif Profetik". Jurnal Pendidikan Karakter IAIN Purwokerto Tahun III No. 3 (2013), 241-242 
yang seharusnya disampaikan kepada siswa. Guru juga harus mampu bertanggung jawab atas kebenaran materi yang disampaikan kepada siswa bilamana terjadi kesalahan dalam pemahaman siswa pada pelajaran yang diajarkan oleh guru dikelas. Karena siswa SD merupakan pusatnya penerimaan materi awal yang bisa berlanjut untuk tahapan sekolah selanjutnya. Jadi bila guru menyampaikan materi yang salah atau tidak sesuai dengan keadaan sebenarnya, maka siswa tersebut akan selalu menggunakan materi yang diajarkan oleh guru pada jenjang sebelumnya. Dan akan menimbulkan kesalahan persepsi pada materi tersebut pada jenjang yang ditempuh saat ini.

2. Sifat Amanah yang menjaga profesionalisme dan komitmen (highly commited).

Seorang guru juga harus selalu profesional dan selalu berkomitmen dalam mengajar di kelas. Yang mana proses mengajar guru

3. Sifat Komunikatif yang mampu mengusai keterampilan berkomunikasi (communication skill).

4. Sifat Cerdas yang sekaligus mampu menyelesaikan masalah (problem solver).

\section{Pembelajaran Matematika di Sekolah Dasar}

Apa tujuan utama pendidikan matematika di sekolah dasar? Secara sederhana, ada satu tujuan utama matematika proses pemikiran anak. Dalam kata-kata David Wheeler, ini lebih bergunauntukmengetahuibagaimanamatematis daripada tahu banyak matematika ${ }^{9}$. Sedangkan

9 David Wheeler, "Mathematisation Matters," For the Learning of Mathematics, 3,1; (1982), hlm. $45-47$ menurut Polya, kita dapat memikirkan dua jenis tujuan untuk pendidikan sekolah: tujuan yang baik dan sempit, untuk mengubah orang dewasa yang dapat dipekerjakan yang pada akhirnya berkontribusi pada pembangunan sosial dan ekonomi; dan tujuan yang lebih tinggi, yaitu mengembangkan sumber daya batin anak yang sedang tumbuh ${ }^{10}$. Berkenaan dengan matematika sekolah, tujuan awalnya secara khusus berhubungan dengan berhitung. Sekolah dasar mengajarkan jumlah dan operasi pada mereka, pengukuran jumlah, pecahan, persentase dan rasio: semua ini penting untuk berhitung.

Dalam mengembangkan sumber daya batin anak, peran yang dimainkan kebanyakan matematika tentang berpikir. Kejelasan pemikiran dan asumsi yang mengarah pada kesimpulan logis sangat penting bagi perusahaan matematika. Ada banyak cara berpikir, dan jenis pemikiran yang dipelajari dalam matematika adalah kemampuan untuk menangani abstraksi. Yang lebih penting lagi, apa yang ditawarkan matematika adalah cara melakukan sesuatu: untuk dapat memecahkan masalah matematika, dan lebih umum lagi, memiliki sikap yang benar untuk memecahkan masalah dan dapat menyerang segala jenis masalah secara sistematis.

Hal ini membutuhkan kurikulum yang terencana, koheren dan mengajarkan matematika sangatlah penting. Kurikulum yang terencana mengandung arti bahwa ia berusaha untuk mencapai tujuan yang lebih tinggi yang disebutkan di atas daripada tujuan yang lebih

10 George Polya, "The goals of Mathematical education", in ComMuniCator, The Magazine of the California Mathematics Council. 1969. 
sempit. Kurikulum harus koheren dalam arti bahwa berbagai metode dan keterampilan yang tersedia sedikit demi sedikit (materi operasi aljabar, aritmatika sosial, sistem bilangan, dan bangun datar) masuk ke dalam kemampuan untuk mengatasi masalah yang berasal dari sains dan studi sosial di sekolah dasar. Kurikulum harus penting dalam arti bahwa siswa merasakan kebutuhan untuk mengatasi masalah tersebut, guru dan siswa beranggapan layak untuk waktu dan energi mereka dalam mengatasi masalah ini, dan bahwa matematikawan menganggapnya sebagai kegiatan yang secara matematis bermanfaat. Perhatikan bahwa kepentingan semacam itu bukanlah hal yang pasti, dan kurikulum dapat membantu membentuknya.

Konsekuensi penting dari persyaratan tersebut adalah bahwa matematika sekolah harus berorientasi pada kegiatan ${ }^{11}$. Dalam pembelajaran matematika di Indonesia, ada sentralitas kepedulian yang berdampak pada semua bidang pendidikan sekolah, yaitu universalisasi sekolah. Ini memiliki dua implikasi penting dalam diskusi kurikulum, khususnya matematika. Pertama, sekolah adalah hak legal, dan matematika menjadi subjek studi wajib, akses terhadap pendidikan matematika berkualitas adalah hak setiap anak. Mengingat kenyataannya di Indonesia, di mana beberapa anak memiliki akses terhadap materi yang mahal, orang tua menginginkan pendidikan matematika yang terjangkau bagi setiap anak, dan pada saat bersamaan menyenangkan. Ini menyiratkan bahwa matematika yang diajarkan terletak pada realitas hidup anak, dan bahwa untuk sistem ini, bukan subjek yang lebih penting daripada anak itu, tapi sebaliknya.

11 National Council of Educational Research and Training. "National Focus Group On Teaching of Mathematics". 2006.
Kedua, di suatu negara di mana hampir setengah anak putus sekolah di tingkat sekolah dasar, kurikulum matematika tidak dapat didasarkan hanya pada persiapan untuk pendidikan dasar, pendidikan menengah dan universitas yang lebih tinggi. Menurut Permendikbud wajib belajar siswa yang diterapkan oleh pemerintah Indonesia adalah 12 tahun $^{12}$. Dimana siswa harus menempuh jenjang dari mulai pendidikan dasar sampai pendidikan menengah. Pemerintah berupaya untuk meningkatkan potensi dimasing-masing daerah agar melek pendidikan dan tahu betapa pentingnya pendidikan bagi siswa. Maka adil untuk bertanya apa dua belas tahun menawarkan matematika sekolah untuk anak-anak semacam itu dalam hal tantangan yang akan mereka hadapi sesudahnya.

Dalam harapan dan tujuannya, pelaksanaan pembelajaran matematika di sekolah dasar sebagai berikut.

1. Anak-anak belajar untuk menikmati matematika. Ini adalah tujuan penting, berdasarkan pada premis bahwa matematika dapat digunakan menikmati hidup lama, dan karenanya sekolah itu paling baik ditempatkan untuk menciptakan rasa seperti matematika. Di sisi lain, menciptakan (atau tidak menghilangkan) ketakutan akan matematika dapat menghilangkan anak-anak dari kebiasaan dan mindset bahwa matematika itu menyenangkan.

2. Anak-anak belajar matematika penting. Menyamakan matematika dengan formula dan prosedur mekanis memang sangat merugikan. Memahami kapan dan bagaimana teknik matematika digunakan selalu lebih penting daripada mengingat kembali teknik dari ingatan (yang mungkin mudah dilakukan

12 Permendikbud No. 19 Tahun 2016 
dengan menggunakan buku), dan sekolah perlu menciptakan pemahaman semacam itu.

3. Anak-anak melihat matematika sebagai sesuatu untuk dibicarakan, dikomunikasikan, dan untuk mendiskusikannya diantara mereka dan teman-temannya agar mampu bekerja sama untuk menyelesaikan yang timbul dalam proses pembelajaran di kelas maupun di luar kelas. Membuat matematika sebagai bagian dari pengalaman hidup anak-anak adalah pendidikan matematika terbaik.

4. Anak-anak bekerjasama dan memecahkan masalah yang berarti di sekolah, matematika adalah domain yang secara formal menangani pemecahan masalah sebagai keterampilan. Mengingat bahwa ini adalah kemampuan untuk digunakan dalam semua kehidupan seseorang, teknik dan pendekatan yang dipelajari di sekolah memiliki nilai yang besar. Matematika juga memberi kesempatan untuk membuat masalah yang menarik, dan menciptakan dialog baru.

5. Siswa memahami secara abstrak untuk melihat hubungan, melihat struktur, hingga alasan tentang berbagai hal tentang matematika, untuk memperdebatkan kebenaran atau kesalahan pernyataan. Pemikiran logis adalah hadiah besar yang bisa ditawarkan oleh matematika kepada kita, dan menanamkan kebiasaan dan pemikiran seperti itu pada anak-anak adalah tujuan utama pengajaran matematika.

6. Anak-anak memahami struktur dasar matematika: operasi aljabar, aritmatika sosial, sistem bilangan, dan bangun datar yang merupakan dasar matematika sekolah, semuanya menawarkan metodologi untuk abstraksi, strukturisasi dan generalisasi. Menghargai ruang lingkup dan kekuatan matematika memurnikan naluri kita dengan cara yang unik.

7. Guru diharapkan untuk melibatkan setiap anak di kelas: Menetap untuk sesuatu yang kurang hanya dapat bertindak terhadap pengecualian dan sistematis, dalam jangka panjang. Cukup menantang talenta bahkan sambil memastikan partisipasi semua anak merupakan tantangan, dan menawarkan sarana dan sumber guru untuk melakukan hal ini sangat penting untuk kesehatan sistem. Visi semacam itu didasarkan pada diagnosis dari apa yang kita anggap sebagai masalah utama yang menimpa pendidikan matematika sekolah di negara ini saat ini, seperti juga pada apa yang kita anggap dapat dilakukan, dan harus dilakukan.

\section{KESIMPULAN}

Dengan adanya berpikir profetik, diharapkan siswa dapat menerapkan pemikiran yang dilakukan oleh Nabi Muhammad SAW. Yang mengacu pada 4 sifat yang dimiliki dan harus diketahui oleh umatnya, yaitu Shiddiq yang berarti benar. Diharapkan siswa dapat menyampaikan informasi secara benar sesuai dengan kenyaatan saat ini. Selain itu perkataan dan perbuatan siswa harus sinkron atau sesuai satu sama lain. Apa yang dikatakan harus sesuai dengan apa yang dilakukan. Hal ini sangat menentukan dalam matematika terutama dalam materi logika matematika. Hal yang benar harus dikatakan benar, hal yang salah harus dikatakan salah. Sifat kedua adalah Amanah yang berarti benar-benar dapat dipercaya. Nabi Muhammad SAW sangatlah dipercaya oleh umatnya. Diharapkan siswa juga mempunyai sifat tersebut agar proses pembelajaran di kelas dapat berjalan sesuai dengan apa yang direncakanakan. Jika suatu pekerjaan atau pengerjaan tugas siswa harus benar-benar mengerjakan sesuai dengan kemampuannya. Ketiga adalah sifat 
Fathonah yang berarti cerdas. Kecerdasan siswa tidak hanya dari ranah kognitif saja, tetapi bisa dinilai afektif dan psikomotor. Seorang siswa dalam belajar matematika dituntut untuk mengembangkan ketiga ranah tersebut karena ilmu dalam matematika tingkat dasar tidak hanya berhitung, tetapi juga adanya ranah praktik. Dan yang terakhir adalah sifat Tabligh yang berarti Menyampaikan. Siswa diharapkan mempunyai sifat ini, karena dalam pembelajaran matematika dilingkup sekolah dasar menyampaikan hasil pengerjaan atau tugas diperlukan agar mengetahui sejauh mana tingkat pemahaman siswa tersebut. Maka dari itu siswa dituntut menyampaikan segala informasi terkait pengerjaan atau tugas yang diberikan oleh guru kepada siswa yang lainnya.

Sementara banyak masalah dan tantangan memperbesar jarak yang perlu kita tempuh untuk sampai pada penglihatan yang diartikulasikan di atas, ini juga menawarkan harapan dengan cara mengarahkan kita ke mana kita harus pergi dan langkah-langkah apa yang mungkin harus kita lakukan. Dari tulisan di atas, dapat kita tarik benang merah apa yang yakini sebagai petunjuk utama dalam proses pembelajaran. Terdapat beberapa pengelompokan materi yang empat tema utama:

1. Pergeseran fokus pendidikan matematika untuk mencapai tujuan 'sempit' menjadi tujuan 'lebih tinggi'

2. Melibatkan setiap siswa dengan rasa percaya diri, sementara pada saat bersamaan menawarkan tantangan konseptual kepada matematikawan yang baru muncul

3. Mengubah cara penilaian untuk menguji kemampuan matematis siswa daripada pengetahuan prosedural

4. Memperkaya guru dengan berbagai sumber matematika. Ada beberapa kebutuhan untuk elaborasi. Pergeseran yang diadvokasi ke tujuan 'yang lebih tinggi' menghilangkan ketakutan akan matematika pada siswa, memungkinkan untuk secara simultan menangani masalah di kelas yang mana siswa mayoritas diam pada saat pembelajaran berlangsung dan siswa yang masih mempunyai motivasi belajar yang rendah. Dan kita sebagai guru bisa menilai proses tidak hanya dari pengetahuan saja, tetapi dari ranah keterampilan dan sikap juga perlu dinilai oleh guru.

Hasil penelitian ini telah berhasil mengembangkan sebuah e-learning yang dinilai layak untuk digunakan sebagai media pembelajaran dan penilaian. Hasil penelitian ini perlu dilanjutkan dengan penelitian tentang pengaruh penggunaan e-learning terhadap motivasi, efikasi diri, kualitas pembelajaran, dan prestasi belajar peserta didik.

\section{DAFTAR PUSTAKA}

Al-Zain. 'Ilmu an-Nafsi: Ma'rifah an-Nafsi al-insaniyah fi al-Kitab wa As-Sunnah. Beirut: Dar Al-Kitab, 1991.

Asy'arie, Musa. Rekonstrukti Metodologi Berpikir Profetik: Perspektif Sunnah Nabi. Yogyakarta: LESFI, 2016.

Azami, Muhammad Mustafa. Studies in Hadith Methodology and Literature. Kuala Lumpur: Islamic Book Trust, 1977.

Dagum, Save M. Kamus Besar Ilmu Pengetahuan, Edisi II, Cet. V. Jakarta: Lembaga Pengkajian Kebudayaan Nusantara, 2006.

Eliade, Mircea (ed.). The Encyclopedia of Religion, Vol. 12. New York: Macmilan Publishing Company, 1987.

Leiden, Brill. "A. Rippin, Muslims: Their Religious Beliefs and Practices" Library of Religious Beliefs and Practices, London: Routledge, no.12 (1990), vol. 1. <http://www.encislam.brill.nl $>$. 
Lings, Marti. Muhammad: Kisah Hidup Nabi Berdasarkan Sumber Klasik, terj. Qamaruddin SF. Jakarta: Serambi, 2007.

National Council of Educational Research and Training. "National Focus Group On Teaching of Mathematics". New Delhi: Bengal Offset Works, Sri Aurobindo Marg, 2006.

Peraturan Menteri Pendidikan dan Kebudayaan Republik Indonesia. No. 19 Tahun 2016.

Polya, George. "The Goals of Mathematical Education", in ComMuniCator, The Magazine of the California Mathematics Council, 1969.

Roqib, Moh. "Pendidikan Karakter Dalam Perspektif Profetik". Jurnal Pendidikan Karakter IAIN Purwokerto Tahun III No. 3, 2013.

Yahya, Harun. The Qur'an Leads the Way to Science. Istanbul: Global Publishig, 2004.

Wheeler, David. "Mathematisation Matters," For the Learning of Mathematics, 3,1, 1982). 